\title{
Prenostica Socratis Basilei, A. Guardo (éd.)
}

\section{G. Matteo Roccati}

\section{(2) OpenEdition}

\section{Journals}

\section{Édition électronique}

URL : http://journals.openedition.org/studifrancesi/10507

DOI : 10.4000/studifrancesi. 10507

ISSN : 2427-5856

\section{Éditeur}

Rosenberg \& Sellier

\section{Édition imprimée}

Date de publication : 1 décembre 2017

Pagination : 526

ISSN : 0039-2944

\section{Référence électronique}

G. Matteo Roccati, «Prenostica Socratis Basilei, A. Guardo (éd.) », Studi Francesi [En ligne], 183 (LXI | III) | 2017, mis en ligne le 01 février 2018, consulté le 23 janvier 2021. URL : http://

journals.openedition.org/studifrancesi/10507 ; DOI : https://doi.org/10.4000/studifrancesi.10507

\section{Ce document a été généré automatiquement le 23 janvier 2021.}

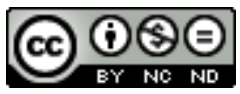

Studi Francesi è distribuita con Licenza Creative Commons Attribuzione - Non commerciale - Non opere derivate 4.0 Internazionale. 


\title{
Prenostica Socratis Basilei, A. Guardo (éd.)
}

\author{
G. Matteo Roccati
}

\section{RÉFÉRENCE}

Prenostica Socratis Basilei, Étude, édition critique et traduction, édition critique par Alberto Alonso GUARDo, traduction de l'espagnol par Nicolas NEGRILLE, Paris, Classiques Garnier, 2015, «Textes littéraires du moyen âge» 35, Série Divinatoria 4, 224 pp.

1 Traduction d'un ouvrage paru en espagnol en 2004. Les Prenostica sont un texte latin en prose et en vers (datable avant 1250), conservé en deux versions appelées «arabe» et «chrétienne». Il en existe aussi deux rédactions françaises (mss. BnF fr. 14776 et 2080, Cambridge, Trinity College 0.5.32) qui dépendent de la version «chrétienne» (elles sont rapidement examinées aux pp. 28-30). L'introduction présente le texte, explique les mécanismes de la divination qui y sont décrits et étudie la tradition manuscrite et les liens entre les deux versions (la version «chrétienne» découle de la version «arabe», mais «elle ne se fonde sur aucun des témoins connus de cette dernière», p. 181). Le texte latin de la version «chrétienne» est accompagné en regard de la traduction en français moderne. En appendice transcription de la version «arabe» (pp. 185-208; d'après le ms. Bodl., Ashmole 304) et étude de sa tradition manuscrite. Bibliographie aux pp. 209-215, Index sélectif et index des manuscrits aux pp 217-219 et 220. 